\title{
Exploring Departmental-Level Fundraising: Relationship-Based Factors Affecting Giving Intention in Arts Higher Education
}

\author{
Yuha Jung ${ }^{1}, \mathrm{PhD} \&$ Min-Young Lee ${ }^{2}, \mathrm{PhD}$ \\ ${ }^{1}$ Associate Professor, Arts Administration, University of Kentucky, 209 Fine Arts Building, USA \\ ${ }^{2}$ Professor, Retail and Tourism Management, University of Kentucky, 303 B Erikson Hall, USA \\ Correspondence: Yuha Jung, PhD, Associate Professor, Arts Administration, University of Kentucky, 209 Fine Arts \\ Building, USA
}

Received: May 10, 2019

Accepted: June 12, 2019

Online Published: June 13, 2019

doi:10.5430/ijhe.v8n3p235

URL: https://doi.org/10.5430/ijhe.v8n3p235

\begin{abstract}
Fundraising for higher education institutions is becoming more important as there is increasingly limited government funding for public education. With shrinking funding, university programs and departments may be expected to raise more income on their own. This study hypothesizes that higher levels of stakeholders' (students and alumni) knowledge, awareness, involvement, satisfaction, and relationship with the department and its fundraising efforts are positively associated with fundraising success measured in intention to give and likelihood to recommend others to give. By using mixed methods research design and relationship fundraising as a theoretical framework, the study found that satisfaction and relationship are the most significant variables positively affecting giving intention. The qualitative results can explain why these variables matter to stakeholders' intentions to give. Using a case study approach of examining one university's arts administration department fundraising practice and its relationship to stakeholders, this research initiates academic and practical discussion on effective fundraising for higher education units.
\end{abstract}

Keywords: institutional advancement, higher education departmental-level fundraising, relationship fundraising, identity theory of giving

\section{Introduction}

As government funding for higher education is decreasing, universities move toward more competitive and market-based allocation of funding (Drezner \& Huehls, 2015; Mitchell, Leachman, \& Masterson, 2016). Thus, there is a greater need for innovative and sustainable fundraising efforts (Weerts, 2007). Most higher education fundraising practice has a centralized structure through college-wide or university-wide development or philanthropy offices (i.e., departments and smaller units of universities rarely have someone in house in charge of fundraising), which may not fully utilize the close relationships alumni have with their smaller unit of studies (e.g., program and department). This larger scale and centralized fundraising of a university is not customized for each constituency group and can be problematic, as it has been known that people will not give unless they have personal connection to a specific cause or organization (Kelly, 1998; Sargeant \& Shang, 2010). Therefore, we posit that institutional fundraising can increase donations by utilizing alumni's personal connection to their unit of studies. Yet the discussion of unit-level fundraising in higher education is extremely limited or nonexistent and this study is one of the first ones to address it using a case study approach.

The study focuses on factors related to fundraising success (using "intention to give" and "recommend others to give") as well as why these factors affect the stakeholders' intention to give as explored from their perspectives. This case study observes the beginning stage of fundraising efforts of one academic unit, the arts administration department at X University, which is a large public research university, in the hope of developing a long-lasting fundraising program for the department for the future. While the case department has been around more than 30 years, its departmental level fundraising is sporadic, and it only recently started formal fundraising programs - an endowment for scholarships and an annual giving program to raise discretionary funds. The leadership realized that it is not taking advantage of the close relationships it has with existing potential donor groups (students and alumni). These groups may not be properly utilized in the university-level development effort as the university in general may not have as strong a relationship with the alumni of the programs within the department. It is time to alter "the impersonal, transactional nature of giving 
between the donor and university" (Conley, 2017, p. 49) and to develop a more interpersonal model of giving that takes advantage of the close personal relationship the department has with its constituencies.

\subsection{Case Study Description and Justification}

There are several reasons for choosing this specific case. First, it is one of the largest arts administration programs in the US. Most arts administration units are programs (not departments) and are small with only one or two full-time faculty members. The subject department currently has five full-time faculty and two full-time staff members, with over 200 undergraduate and graduate students enrolled at a given time in the last five years or so. This provides a larger group of participants for the case study. Second, it teaches fundraising as part of its curriculum (at both the undergraduate and graduate levels) providing a condition to explore how knowledge about fundraising (one of the lesser studied factors in fundraising research) can affect stakeholders' intention to give. Lastly, one of the authors is affiliated with the department providing easy access to the current students and alumni database.

While one case cannot result in generalizable conclusion, we hope this will be a beginning place to start the academic and practical conversation about unit-based fundraising in higher education. Additionally, we recognize that there is general lack of studies on students and young alumni giving motivations and patterns (Freeland, Spenner, \& McCalmon, 2015). As this study includes current students and recently graduated alumni as primary study participants, it helps fill the gap in the understanding of young donors. Lastly, there is a dearth of institutional giving research that utilizes qualitative research methods that solicit various perspectives of the stakeholders. Therefore, this study included a qualitative research method (in-depth interviews with 51 participants) to provide more nuanced understanding of giving intention of students and alumni. The study aims to offer suggestions toward more effective fundraising models and strategies for this department and others in a similar situation (e.g., recently started a fundraising program/campaign or thinking about launching one).

\section{Theoretical Framework: Relationship Fundraising}

This research defines fundraising in a broad sense, beyond simply a function of generating income for nonprofit organizations and universities. Recognizing that successful fundraising is a systematic, sustainable, and relationship-based practice (Drezner \& Huehls, 2015; Burnett, 2002; Kelly, 1998; Sargeant \& Shang, 2010; Weerts, 2007), this study adopted a relationship fundraising approach that sees fundraising as a sustainable relationship-building practice rather than a practice of transaction fundraising, or merely raising funds based on short-term transactions. The emphasis of relationship fundraising is combined with the concept of donorcentrism, or meeting the needs and wants of donors while continuously cultivating relationships with them using genuine two-way symmetric communications (MacQuillin, 2016).

Relationship-based fundraising practice is influenced by the theory of relationship marketing (Drezner \& Huehls 2015). "Relationship marketing refers to all marketing activities directed toward establishing, developing, and maintaining successful relational exchanges" (Morgan \& Hunt, 1994, p. 22). Relationship marketing is in contrast with transaction-based marketing that focuses on several one-time transactions (or donation acts) without engaging customers or donors on a regular basis (Drezner \& Huehls, 2015). In addition, in relationship marketing, the emphasis is on fostering communal relationships, where "both parties provide benefits to the other because they are concerned for the welfare of the other" rather than developing mere exchange relationships, where "one party gives benefits to the other only because the other has provided benefits in the past or is expected to do so in the future" (Hon \& Grunig, 1999, p. 3).

Relationship fundraising is also linked to the identification theory of giving. Identification theory or identity theory (Jackson, Bachmeier, Wood, \& Craft, 1995; Martin, 1994) is based on the idea that when people feel they belong to or identify with the cause of a certain group or organization, they are more likely to give to that organization. Communities of people who identify with each other care about one another and believe that by helping the community, they are mutually benefiting all members of that community (Drezner \& Huehls, 2015; Martin, 1994). They are therefore further fostering communal relationships, as explained by Hon and Grunig (1999). Another theory that can support the legitimacy of relationship fundraising is continuity theory (Atchley, 1989), which explains that repeated actions are more likely to be sustained (Drezner \& Huehls, 2015). Applying this theory to fundraising, donors are more likely to give regularly when their relationships with specific organizations are repeatedly fostered and maintained (Lindahl \& Winship, 1992; Piliavin \& Charng, 1990).

However, relationship marketing and fundraising strategies may not work for all situations as some companies may not need to complicate their process of marketing, especially if their sole goal is to maximize income (Sargeant, 2016).

Rather, it may be more appropriate for a nonprofit context, where stakeholder involvement is possible, such as in major 
gifts, "where both parties are desirous of a relationship and engage in enhanced social interaction" (Sargeant, 2016, p. 27). University units are in a prime situation to engage their current and future donors (e.g., students and alumni) by regularly interacting with them for a long-term (i.e., duration of getting a degree) through formal classes (e.g., coursework) and informal activities (e.g., fieldtrips, social gatherings, etc.), making relationship fundraising an ideal framework for university unit-level fundraising endeavors.

\section{Factors Influencing Giving in Higher Education Fundraising}

Some of the common factors associated with giving to nonprofit organizations as well as universities are sociodemographic characteristics, such as income and wealth (Baade \& Sundberg, 1996; Clotfelter, 2003; Marr, Mullin, \& Siegfried, 2005), gender (Eckel \& Grossman, 1998), and race (Billings, 2013; Monks, 2003). For example, the positive relationship between income level and giving have been well recorded (Baade \& Sundberg, 1996; Clotfelter, 2003; Marr et al., 2005). Women tend to be more generous than men (Eckel \& Grossman, 1998) and people of color may give less compared to white people (Monks, 2003). While demographics are important factors in giving, they are not appropriate to examine in this study since they largely have been tested in previous research and our sample size is not large enough due to its nature as a case study. However, in the literature review below we further identify specific factors that are closely related to genuine and continuous relationship building which ultimately affect the giving intentions and behaviors of donors. While we pull from fundraising literature in general, we mostly focus on the higher education fundraising context.

\subsection{Relationship and Satisfaction}

Relationship, or the degree of being connected to the organization or belongingness (Drezner \& Huehls, 2015; Schervish \& Havens, 1997; Kelly, 1998; Sargeant \& Shang, 2010; Jackson et al., 1995), is an important factor when the decision of where to give is made by individuals. The sense of being connected is one of the reasons to make gifts (Jackson et al., 1995). When positive relationships and a sense of belongingness are manifested in the form of donations (either money or time, regardless of the amount) and continuously cultivated, the act of philanthropy toward the specific organization will likely continue in the future. In fact, one of the best predictors for current and future giving, especially major giving, is patterns of prior giving to an institution (Kelly, 2002; Lindahl \& Winship, 1992; Freeland, et al., 2015; Conley, 2017). This is proven to be applicable in higher educational settings as a culture of giving developed in students' early college years affects their giving after graduation in a positive way (Freeland et al., 2015).

The connection can be manifested in the feeling that one develops a sense of identification with an organization leading to further social bonds or stronger relationships (Sargeant, 2016). Some of the components toward building strong and quality relationships are trust, commitment, and satisfaction (Sargeant \& Lee, 2004). Trust is an important aspect in developing relationships. Studies have shown that the more trustworthy an organization is (that it would fulfill what it has promised), the more donors are likely to give (Sargeant \& Lee, 2004). In addition, commitment, which is a related concept of loyalty and desire to maintain a relationship (Moorman, Deshpande, \& Zaltman, 1993), drives being loyal to an organization, which is the desire and act of maintaining relationships for the future (Morgan \& Hunt, 1994). Satisfaction is defined as fulfillment of one's expectations of an organization or party, usually generating a positive feeling toward it, and is one of the most important factors affecting donor loyalty and therefore furthering relationships (Sargeant, 2016). In addition, Sargeant (2001) found that donors are twice as likely to give a second or subsequent gift when they are very satisfied as compared to those who are just satisfied. According to Sun, Hoffman, and Grady (2007), satisfying educational experiences are positively related to increased institutional giving. Other scholars agree that the quality of student experiences act as a strong indicator of alumni giving (Billings, 2013; Clotfelter, 2003; Hurvitz, 2013; Marr et al., 2005; Monks, 2003; Gaier, 2005). Students' satisfaction is also influenced by whether they received scholarships, and studies have proven that receiving scholarships is positively related to alumni donation (Cunningham \& Cochi-Ficano, 2002; Marr et al., 2005).

\subsection{Involvement}

Involvement or participation, the condition and action of being involved or taking part in something, is also proved to be a positive factor influencing likelihood of giving (Freeland at al., 2015; Schervish \& Havens, 1997). Nayman, Gianneschi, and Mandel (1993) stated that effective student involvement or participation in institutional advancement would establish a foundation for future alumni involvement and giving. Involvement of students and alumni in the giving process or experiences early on (e.g., involvement with alumni associations, giving challenges, and other extracurricular activities related to giving) would affect giving even more (Hurvitz, 2013; Monks, 2003; Nayman et al., 1993). Additionally, the more a person is involved with an organization, the more the person is likely to identify with the organization (Burke, 2000). This can be applied to higher education fundraising where more involvement of 
students and alumni can help them identify more closely with their program of studies or schools, possibly leading to more giving in the future.

\subsection{Knowledge and Awareness}

Another factor related to motivation for giving among students, alumni, and other higher education stakeholders is knowledge, an understudied factor in existing studies on institutional giving. While cultivating relationships are important steps toward sustainable and major giving, higher education stakeholders should know the meaning and purpose of philanthropy (Hurvitz, 2013) for them to even consider giving. This is also related to awareness of fundraising opportunities, as not being asked (i.e., not knowing about a current funding opportunity or that it is possible to donate to a certain organization) is one of the number one reasons for not giving (MacQuillin, Sargeant, and Shang, 2016). Teaching about philanthropy and that anyone can make a difference by giving regardless of their status could influence constituencies to donate when they have more capacity in the future (Bjorhovde, 2002). While some studies (Bjorhovde, 2002; Hurvitz, 2013) advocate for constituencies being more knowledgeable about philanthropy through informal channels such as alumni associations, ambassador programs, and fundraising clubs, no study discusses how formal courses in fundraising and the professional fundraising experiences of stakeholders would influence their intention to give in higher educational settings.

\section{Hypotheses, Research Question, and Methods}

Table 1. Dependent and Independent Variables and Their Measurements

\begin{tabular}{|c|c|c|}
\hline Variables & Type & Measurements \\
\hline Fundraising success & DV & $\begin{array}{l}\text { Intention to give money and time and likelihood to } \\
\text { recommend others to give to the department (1-7 Likert } \\
\text { scale) }\end{array}$ \\
\hline Participants' level of knowledge of fundraising & IV & 1-7 Likert scale \\
\hline $\begin{array}{l}\text { Participants' level of awareness of fundraising } \\
\text { efforts in the department }\end{array}$ & IV & 1-7 Likert scale \\
\hline $\begin{array}{l}\text { Participants' level of involvement in the } \\
\text { department's fundraising efforts }\end{array}$ & IV & 1-7 Likert scale \\
\hline Participants' satisfaction with the department & IV & $\begin{array}{l}\text { Level of satisfaction with faculty, staff, other students, and } \\
\text { department's fundraising efforts (1-7 Likert scale) }\end{array}$ \\
\hline $\begin{array}{l}\text { Participants' level of relationship with the } \\
\text { department }\end{array}$ & IV & Level of connection and belongingness (1-7 Likert scale) \\
\hline
\end{tabular}

Based on the literature review in Section 3, we identified five independent variables. We included knowledge about fundraising because knowing that fundraising is more than raising money and recognizing it as a necessary and legitimate management function of a nonprofit would encourage people to give. Awareness of fundraising efforts or giving opportunities, although not much discussed in existing literature, is included as not knowing about the opportunities to give would affect constituents' charitable donations. We included involvement as involving students and alumni in the giving process or experiences early on would affect their intention to give. Satisfaction is included as satisfying educational experiences would also positively affect institutional giving as shown in literature review above. Lastly, relationship measured in the level of connection and belongingness is included as an independent variable to predict one's intention to give. The study's dependent variable is fundraising success measured in intention to give money and time and likelihood to recommend others to give to the department, which indicates the success level or potential for successful fundraising for the future (See Table 1 for more details). The reason that we used intention to give and likelihood to recommend others to give instead of actual giving to measure fundraising success is that (1) the study participants are mostly students and young professionals who have not given to the department in the past and (2) the department has a short history of having a formalized fundraising effort.

The study's quantitative research tests the following study hypotheses: The higher levels of (1) knowledge about fundraising, (2) awareness of fundraising efforts of the department, (3) involvement with the department's fundraising efforts, (4) satisfaction with the department, and (5) relationship with the department are positively associated with the intention to give and likelihood to recommend others to give. The qualitative part of the study will answer why these variables do or do not influence these specific stakeholders' intention to give and recommend others to give to the 
department. It also can complement what is found from the quantitative analysis, providing further context for each variable discussed.

The study uses a mixed methods research design and is specific to one case based on one public research university's arts administration department. Primary study participants were current students (both undergraduate and graduate students) and alumni of the BA and MA degree programs in arts administration. We only included stakeholders who are close to the unit as they are the primary donors and potential donors to the unit. In other words, we did not include community members or others who may be interested in giving to the unit despite their lack of formal affiliation to the department. The study utilized online surveys and in-depth interviews (in-person and via telephone).

Table 2. Demographic Information of Survey Participants

\begin{tabular}{|c|c|c|}
\hline Demographics & $\mathbf{N}$ & $\%$ \\
\hline \multicolumn{3}{|l|}{ Gender } \\
\hline Male & 30 & $24.0 \%$ \\
\hline Female & 94 & $75.2 \%$ \\
\hline No response & 1 & $0.8 \%$ \\
\hline \multicolumn{3}{|l|}{ Age } \\
\hline $18-26$ & 48 & $38.4 \%$ \\
\hline $27-36$ & 44 & $35.2 \%$ \\
\hline $37-46$ & 21 & $16.8 \%$ \\
\hline 47 and above & 5 & $4.0 \%$ \\
\hline No response & 7 & $5.6 \%$ \\
\hline \multicolumn{3}{|l|}{ Marital Status } \\
\hline Single & 53 & $42.4 \%$ \\
\hline In a relationship & 22 & $17.6 \%$ \\
\hline Married & 45 & $36.0 \%$ \\
\hline Divorced & 4 & $3.2 \%$ \\
\hline Other & 1 & $0.8 \%$ \\
\hline \multicolumn{3}{|l|}{ Income } \\
\hline Less than $\$ 35000$ & 44 & $35.2 \%$ \\
\hline$\$ 35001-\$ 50000$ & 22 & $17.6 \%$ \\
\hline$\$ 50001-\$ 70000$ & 15 & $12.0 \%$ \\
\hline$\$ 70001-\$ 100000$ & 19 & $15.2 \%$ \\
\hline$\$ 100001-\$ 150000$ & 14 & $11.2 \%$ \\
\hline More than $\$ 150000$ & 9 & $7.2 \%$ \\
\hline No response & 2 & $1.6 \%$ \\
\hline \multicolumn{3}{|l|}{ Education } \\
\hline Some college/Associate degree & 21 & $16.8 \%$ \\
\hline 4-year college degree & 63 & $50.4 \%$ \\
\hline Graduate degree & 40 & $32.0 \%$ \\
\hline No response & 1 & $0.8 \%$ \\
\hline
\end{tabular}

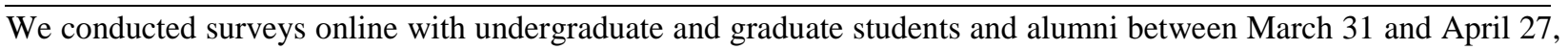
2016. The surveys were sent to all current students and alumni (a total of about 400 individuals), and we received a total of 132 responses. We excluded seven surveys from the analysis because most of the questions were not answered. Survey participants were composed of 48 current students (38\%) and 77 alumni (62\%). All survey participants received a $\$ 10$ Amazon gift card to incentivize participation. The response rate for surveys was $33 \%$. The detailed 
demographic information of the survey responders is in Table 2. More than $75 \%$ of the responders were female and about $74 \%$ of them are aged between 18 and 36. Approximately $42 \%$ said they are single and $54 \%$ of them are either married or in a relationship. The income level is widely distributed with the largest group (35\%) making less than $\$ 35$ 000 a year. This is presumably due to the majority of participants being students and recent graduates. Participants are highly educated as $82 \%$ have a 4-year college degree or higher. The survey results also identified that only $20 \%$ of them are past and current donors to the department, possibly because the department only recently initiated fundraising programs.

Table 3. Variable Measurements and Their Reliability

\begin{tabular}{llc}
\hline Variables & Questions & Reliability \\
\hline Knowledge & How would you rank your prior knowledge about fundraising in general? & N/A \\
Awareness & $\begin{array}{l}\text { How would you rank your awareness of the fundraising efforts of the } \\
\text { department? }\end{array}$ & N/A \\
Involvement & $\begin{array}{l}\text { How would you rank your level of involvement in the fundraising efforts of } \\
\text { the department? }\end{array}$ & N/A \\
Satisfaction & $\begin{array}{l}\text { How satisfied are/were you with your interactions with the faculty in the } \\
\text { department? }\end{array}$ & 0.79 \\
& $\begin{array}{l}\text { How satisfied are/were you with your interactions with the staff in the } \\
\text { department? }\end{array}$ & \\
& $\begin{array}{l}\text { How satisfied are/were you with your interactions with other students in the } \\
\text { department? }\end{array}$ & \\
& $\begin{array}{l}\text { How would you rank your level of satisfaction with the fundraising efforts of } \\
\text { the department? }\end{array}$ & \\
Relationship & $\begin{array}{l}\text { How connected do you feel to the department? } \\
\text { Would you describe yourself an active member of the department? }\end{array}$ \\
Donation & $\begin{array}{l}\text { How likely are you to give money to the department now? } \\
\text { Intention }\end{array}$ & $\begin{array}{l}\text { How likely are you to give money to the department in the future? } \\
\text { How likely are you to recommend other people to donate to the department? }\end{array}$ \\
& How likely are you to give your time to the department?
\end{tabular}

Table 3 shows how each variable was measured in the survey questions. Knowledge, awareness, and involvement were measured by a single item as indicated in Table 3. Satisfaction, relationship, and fundraising success are composite variables which were measured by multiple items. Cronbach's $\alpha$ was used to measure the internal reliability of these composite variables. The Cronbach's $\alpha$ of relationship, satisfaction, and donation intention is $0.92,0.79$, and 0.77 , respectively. According to Guielford's (1965) suggestion, when Cronbach's $\alpha$ is greater than 0.7, it shows the questionnaire has a relatively high internal reliability. The results indicate that the reliability of the questionnaire is acceptable. Multicolliniarity was also assessed using the variance inflation factors (VIF). VIF scores ranged between 1.13 to 1.58 . A VIF score exceeding 10 is regarded as indicating serious multicolliniarity. Values less than 4 suggest that it is not great concern of the stability of the parameter estimates (Glantz \& Slinker, 1990).

For students and alumni interviews, we started with the existing student and alumni database in the department and randomly selected potential participants from the list. They were contacted by the research assistant and invited to participate in interviews. Interview participants included 51 individuals: 15 undergraduate students, 15 graduate students, and 21 alumni. All interviews were conducted between November 2015 and March 2016. We offered a $\$ 30$ Amazon gift card for all interview participants to incentivize their participation. The interviews were designed to identify and investigate the important factors affecting intention to give from stakeholders' perspectives, while the surveys were designed to illustrate the relationship between dependent and independent variables. As they had different purposes and included different questions, we allowed interview and survey participants to overlap. Both surveys and interviews were conducted confidentially so pseudonyms are used for interview participants in the results in Section 6. A professional transcribing company transcribed all interviews.

We used simple regression analysis and qualitative content analysis (Glaser \& Strauss, 1967; White \& Marsh, 2006) to analyze quantitative and qualitative data, respectively. We organized survey results and analyzed them using descriptive statistics and simple regression analyses in SPSS using the variables and measurements in Table 1. We 
organized the qualitative data into overarching themes, categories, and subcategories and then created a visual matrix of them. Then we finalized these categories, formed more elaborate patterns, interpretations, and arguments that are closely related to the research question.

\section{Quantitative Results}

The study hypothesized higher levels of knowledge, awareness, involvement, satisfaction, and relationship are positively associated with stakeholders' intention to give. The regression results show that all five independent variables are positively related to intention to give, with relationship being the most significant and knowledge being least significant.

\subsection{Knowledge and Awareness}

As shown in Table 4, knowledge $(\beta=0.25, \mathrm{p}=0.01)$ and awareness $(\beta=0.44, \mathrm{p}<0.001)$ were positively related to donation intention although awareness is a better indicator than knowledge. About $65 \%$ of the participants ranked their knowledge about fundraising in general to be knowledgeable to very knowledgeable. Nearly $67 \%$ of the participants said that they have taken fundraising courses as part of the department's curriculum and $20 \%$ plan to take it in the future. While this is not a direct indication of the participants' level of understanding in fundraising knowledge, it implies that most participants understand the concept and importance of fundraising especially in the arts administration context. Although knowledge is the least impactful factor affecting intention to give among the five variables, the knowledge level of constituents can potentially affect the fundraising success of the department in the future (Bjorhovde, 2002).

Table 4. Regression Analysis of Factors Influencing Donation Intention

\begin{tabular}{lccccc}
\hline Variables & $\boldsymbol{\beta}$ & $\mathbf{R}^{2}$ & $\mathbf{t}$ & $\mathbf{F}$ & Sig \\
\hline Knowledge & 0.25 & 0.06 & 2.88 & 8.27 & 0.01 \\
Awareness & 0.44 & 0.19 & 5.40 & 29.17 & 0.00 \\
Involvement & 0.41 & 0.17 & 5.00 & 25.00 & 0.00 \\
Satisfaction & 0.46 & 0.21 & 5.74 & 32.97 & 0.00 \\
Relationship & 0.63 & 0.39 & 8.80 & 77.47 & 0.00 \\
\hline
\end{tabular}

In terms of awareness, about $56 \%$ of survey participants answered that they were contacted by the department regarding its current fundraising efforts for the scholarship endowment program or annual giving program. About a half of interview participants also mentioned that they had received emails from the department about its fundraising programs, while the rest said either they do not pay attention to them or do not remember receiving these emails. Some even said that they are not receiving emails from the department at all. This is a problem, as not being asked is a well-recorded reason for not giving (MacQuillin et al., 2016). The survey results of this study concur, with more than $30 \%$ of respondents (the largest group) chose "They were never asked" as their number one reason for not giving. Therefore, letting stakeholders know of giving opportunities is one of the important steps in initiating the first gift, which can lead to future giving.

\subsection{Involvement}

Involvement is also positively and significantly related to donation intention $(\beta=0.41, p<0.001)$, echoing other studies demonstrating the close and positive relationship between involvement and giving (Freeland et al., 2015; Nayman et al., 1993; Schervish \& Havens, 1997). However, most survey participants said that they are not involved in the fundraising efforts of the department, with $90 \%$ of responders saying that their level of involvement is not involved to rarely involved. This is concerning as involvement is one of the most important factors in people identifying with certain organizations (Burke, 2000), which in turn can lead to deeper relationships and more giving.

\subsection{Satisfaction and Relationship}

More importantly, satisfaction $(\beta=0.46, p<0.001)$ and relationship $(\beta=0.63, p<0.001)$ are positively and significantly related to donation intention, with relationship being the most influential factor. Many studies have shown that satisfying educational experiences are positively related to institutional giving (Billings, 2013; Clotfelter, 2003; Hurvitz, 2013; Marr et al., 2005; Monks, 2003; Sun et al., 2007). We found this to be true in our study as students and alumni who thought they benefitted from the department and were satisfied by the instruction and quality of the department are more likely to give. Most survey participants were satisfied with experiences in the department; we found that $87 \%, 82 \%$, and $85 \%$ of the participants reported that they were satisfied to very satisfied about faculty, staff, 
and other students in the department, respectively. Due to the strong connection between satisfaction and intention to give, this is good news for the department.

Relationship - the level of belonginess and connectedness - is the most significant factor affecting donation intention. This has been much discussed in other studies (Drezner \& Huehls, 2015; Schervish \& Havens, 1997; Kelly, 1998; Sargeant \& Shang, 2010; Jackson et al., 1995), demonstrating that the degree of relationships and feeling of connectedness are some of the most important factors in one's decision to give. Yet, only $35 \%$ and $40 \%$ of the survey participants described themselves as active members of the department or feeling connected to the department, respectively. As $60 \%$ of the survey participants were alumni, it makes sense that $35 \%$ of the survey participants said they are not active members of the department. However, it is concerning that only $40 \%$ of survey participants feel connected to the department. This could be related to the lack of awareness among stakeholders as the department has not been reaching out to some, by not letting them know about giving opportunities or what is happening in the department.

\section{Qualitative Results}

We explored why the variables tested above affect participants' intention to give money and time and likelihood to recommend others to give to the department through in-depth interviews.

\subsection{Knowledge and Awareness}

Many participants shared that their level of knowledge in fundraising in general helps them understand fundraising and its importance, especially those who have taken fundraising courses or alumni working in the field as fundraisers. Because of that they can be more sympathetic when being asked to donate. One alumnus stated, "It does help me to be a little more understanding and I am fairly nice to people that call me...just because I understand it [fundraising] is necessary" (Mark, interview by author, December 1, 2015). As a result, many participants wanted to give more. As one alumna said, "I probably wouldn't give back much if I didn't know all the work that goes into it" (Jessica, interview by author, November 25, 2015). Some with no or shallow understanding simply explained it to be raising money through events, which is only a fraction of what fundraising is about. These participants tended to be less inclined to think about giving or did not know they could give to the department.

The results of interview analysis made it clear that awareness is important when it comes to fundraising because awareness can lead to opportunities to give. In other words, if potential donors do not know that they can be donors and do not know how to give, they will never give. One undergraduate student, who did not know that she could give to the department, said, "Other than the tuition that I'm giving, I did not know that there was a thing [giving opportunity or program]" (Julie, interview by author, November 21, 2015). In addition, simply getting solicitation emails or newsletters does not necessarily lead to awareness. One alumnus said, "I mean I know I get them [emails and newsletters] but I don't really pay attention that much. I can credit basically seventy-five percent of my success to the program but haven't really thought about it [giving]" (Ted, interview by author, December 10, 2015). It is the department's job to market the fundraising efforts effectively on a personal level, so constituents are clearly aware of various giving opportunities. As shown in the regression results above, when they are more aware, they are more likely to consider giving.

\subsection{Involvement, Satisfaction, and Relationship}

Students' active involvement in fundraising can lead to more intention to give from potential donors as they can feel more personal connection to the person who is soliciting. For this reason, alumni wanted to see more current students involved in fundraising efforts of the department. One alumnus said, "I think once or twice I would get a [solicitation] call from actually X University students; somebody who is in the program... as opposed to somebody who is completely removed and is calling because you are next on their list" (Mark, interview by author, December 1, 2015). This alumnus and others added that they are more likely to give when a student in the department calls as opposed to a professional fundraiser who does not have a deep understanding of or direct connection to the department. Solicitation based on personal connection has been proven to be effective in other studies (Meer, 2011; Meer \& Rosen, 2011).

Participants often credited the department and its education for their success and told us that they wanted to give back so other students can have the same experiences or benefits. One alumna said, "Yeah, it's mainly enjoying the program and wanting to support it. I really enjoyed my time there and I feel like it served me well for the rest of my life" (Jamie, interview by author, December 4, 2015). In many cases, participants specifically pointed out what helped them when they were in school and wanted to give back to that specific cause. An undergraduate student said he will give to the department after he graduates and gets a job because he likes to give back to the endowment fund from which he benefited. He added, "It has benefited me and I'm reaping the benefits from the money of others" (Michael, interview 
by author, November 19,2015). This has been found in other studies where students are more likely to give to their schools when they received need-based scholarships or awards (Cunningham \& Cochi-Ficano, 2002; Marr et al., 2005).

Participants said that they give to organizations with which they have prior and good relationships with because the process of building relationships (e.g., frequent interactions with and care from the organization) makes them feel emotionally attached or that they belong. When they felt like they were just a name on a list or have recently developed a negative experience in donating money or time to an organization, they no longer felt connected and as a result stopped giving. For example, one alumna shared that being asked by an organization that does not try to foster relationships is a reason for not giving. She shared, "My husband went to Y University and ... once a year he'll get a call from them asking for money, and he is not really involved with them anymore. I think sometimes this can be a turnoff if you have lost track of what they do. And they kind of call out of the blue and ask for money, when you haven't had any other contact" (Emily, interview by author, December 5, 2015). This strategy follows a transaction-based marketing in fundraising, relying on several one-time transactions, rather than cultivating sustained relationships or belongness (Sargeant \& McKenzie, 1998; Drezner \& Huehls, 2015). As a contrary example, one alumna shared a story of her former professor and donating to an endowment that was named after the professor. She said, "I don't think I would have developed an emotional connection with the program if I hadn't enjoyed the program or developed a special relationship with the professor. That is the reason I am supporting the program now and have given to its cause" (Kim, interview by author, December 15, 2015).

\section{Toward Sustainable Relationship Fundraising for Higher Education Units}

As mentioned in Section 5, the findings of the study indicate that while all variables (knowledge, awareness, involvement, satisfaction, and relationship) tested were positively related to intention to give, relationship was the most significant factor affecting one's intention to give to the department. Satisfaction was the second most significant factor while knowledge was least significant.

\subsection{Discussion of Results}

Through qualitative interviews and analysis, we also explored reasons behind why these variables matter from the participants' perspectives, adding more nuanced understanding to students and alumni giving patterns to their universities. As indicated in the results section, some of our findings are consistent with the existing works while some contributing to advancing existing research. For example, while knowledge has a least statistical significance, the qualitative discussions with participants revealed that especially in the arts administration unit context (or other programs that teach fundraising as part of their curriculum), teaching fundraising as part of core curriculum may have positive externalities of "raising" responsible future donors not only for their unit of studies but for the society in general (i.e., they may be more likely to donate to other nonprofits). The relevance of awareness to intention to give found in this study tells that when giving opportunities are not well communicated to potential donor groups, it may create a great deal of missed opportunities.

Fostering the feeling of belonginess and connectedness among stakeholders are the most important part of successful fundraising, and continuously developing these relationships will lead to long-term fundraising success. In this long-term and somewhat repeated process, stakeholders can truly identify with the department, creating a sense of community whose wellbeing matters to them because it provides mutual and communal benefits to all members. According to identity theory, which is considered critical in developing future direction of relationship fundraising (MacQuillin \& Sargeant, 2016), fostering a sense of group identity could "bolster longevity in relationships" (p. 12). Therefore, this continuous effort to develop genuine relationships can further maintain the belongingness of stakeholders to the department, leading to cultivation of a unique sense of group identity as, for example, "supporters of X University's department of arts administration.”

\subsection{Relationship Fundraising as Units}

Developing this group identity can be more easily achieved in a higher education unit setting, such as a program or a department, as students spend a significant amount of their time in school interacting with the unit's faculty, staff, and other students for multiple years. As a result, they often develop a sense of, and strongly identify with, that community. The unit's job is then to make sure the students and alumni understand there are many ways they can contribute to their community, paying attention to the need for more effective marketing approaches that go hand in hand with fundraising strategies.

Additionally, some of the factors discussed can be promoted together to foster long-lasting, genuine, and communal relationships. For example, involvement and satisfaction not only affect stakeholder's intention to give but they are 
also two of the most important factors in fostering communal and genuine relationships (MacQuillin et al., 2016; Sargeant, 2016). Therefore, to develop a unique sense of group identity among the stakeholders, involvement in fundraising activities can help constituents feel more a part of the organization. Students wanted to have more hands-on experiences, alumni wanted more involvement of students in soliciting, and the participants in general wanted to be involved with organizations to which they are giving. To reflect these sentiments, educational units should involve their students in their fundraising tasks whether small or big. In addition, to keep stakeholders satisfied, higher education units should keep up with best practices. For example, units should continue providing relevant and updated curriculum, hire and develop qualified and caring faculty and staff, and strive to build a sense of community to continuously provide satisfying education and experiences to their constituencies. These should be considered part of holistic fundraising strategy.

A holistic fundraising strategy cannot be successful when an effort only comes from a unit leader or development officer. For example, faculty and staff of the department were influential elements when it came to creating satisfying educational experiences through developing and offering courses and extracurricular activities, involving students in fundraising activities and teaching them about it through course work, as well as building long-lasting relationships with them through genuine and caring interactions. Therefore, this holistic approach to unit-level university fundraising necessitates buy-in from all faculty, staff, and students. Involving the whole unit is crucial to success as many parts of the unit have been influential in students feeling more emotionally attached even after they graduate.

\section{Conclusion}

The study used a mixed methods research design, qualitative content and regression analyses, and relationship fundraising as a theoretical framework to explore the factors related to fundraising success (measured in intention to give and likelihood to recommend others to give) as well as why these factors affect the stakeholders' intention to give. We answered them by identifying and testing five factors affecting fundraising success and by soliciting nuanced reasons on why they matter from participants' perspectives. While all factors tested are relevant, satisfaction and relationship were the most important factors positively affecting giving intention. The qualitative analyses of interviews provided reasons for why these factors influenced their intention to give. Participants are more likely to give and recommend others to give to the department because: (1) understanding more about fundraising helps see fundraising is necessary and important, leading them to be more sympathetic when they are solicited; (2) being aware of fundraising efforts can lead stakeholders to spot actual giving opportunities and help realize that they could give; (3) involving students in the fundraising efforts can lead to making more personal connections with potential donors, especially alumni; (4) participants who are satisfied with the department are often due to specific reasons (e.g., high value of education or scholarships) and they like to reciprocate by donating; and (5) past and existing relationships with the department (especially with faculty) created the feeling of connection and belongness, making them emotionally attached.

To have more sustainable relationship fundraising, it is important to foster the feeling of belonginess and connectedness among stakeholders eventually leading to future fundraising success. Through more effective marketing approaches to make stakeholders aware of giving opportunities, involving them in various fundraising and departmental efforts, and creating satisfying educational experiences though the efforts that involve the whole unit, not just the ones who oversee fundraising function of the unit, units can create a unique sense of community where stakeholders can identify themselves as members of a strong community.

\subsection{Limitations and Future Research}

There are several limitations to the study. First, its participants are from one university in one disciplinary area of arts administration. Therefore, its results cannot be directly applied across all educational units. Second, this study is not exhaustive in identifying and testing all relevant factors affecting fundraising success. For example, we did not include trust and commitment as part of variables tested. In hindsight they should have been included as they are important factors influencing relationship formation. Additionally, since nearly $67 \%$ of study subjects had taken a fundraising course, the study cannot be readily generalized to other university units that do not offer fundraising courses as part of core curriculum. Future studies may include a number of units from several different universities and disciplines to produce more generalizable results from larger sample sizes and could be based on multi-year data to keep track of participants' giving patterns. These studies could be more exhaustive including a wide variety of variables to truly understand what is important and not important and why in studying unit-based fundraising practices in higher education. 


\section{References}

Atchley, R. C. (1989). A continuity theory of normal aging. The Gerontologist, 29(2), 183-190. https://doi.org/10.1093/geront/29.2.183

Baade, R. A., \& Sundberg, J. O. (1996). What determines alumni generosity? Economics of Education Review, 15(1), 75-81. https://doi.org/10.1016/0272-7757(95)00026-7

Billings, M. S. (2013). Examining young alumni giving behavior: Every dollar matters. In N. Drezner (Ed.), Expanding the donor base in higher education: Engaging non-traditional donors (pp. 102-119). New York, NY: Routledge.

Bjorhovde, P. O. (2002). Teaching philanthropy to children: Why, how, \& what. New Directions for Philanthropic Fundraising, 36, 7-20. https://doi.org/10.1002/pf.3601

Burke, P. J. (2000). The present, past \& future of an identity theory. Social Psychology Quarterly, 63(4), 284-297. https://doi.org/10.2307/2695840

Burnett, K. (2002). Relationship fundraising: A donor-based approach to the business of raising money. London, UK: The White Lion Press.

Clotfelter, C. (2003). Alumni giving to elite private colleges \& universities. Economics of Education Review, 22(3), 109-120. https://doi.org/10.1016/S0272-7757(02)00028-6

Conley, A. T. (2017). Securing donor support for unrestricted endowments: A case study in higher education. Philanthropy \& Education, 1(1), 48-63. https://doi.org/10.2979/phileduc.1.1.04

Cunningham, B., \& Cochi-Ficano, C. K. (2002). The determinants of donative revenue flows from alumni of higher education: An empirical inquiry. Journal of Human Resources, 37(3), 540-569. https://doi.org/10.2307/3069681

Drezner, N. D., \& Huehls, F. (2015). Fundraising \& institutional advancement: Theory, practice, \& new paradigms. New York, NY: Routledge. https://doi.org/10.4324/9780203123850

Eckel, C., \& Grossman, P. (1998). Are women less selfish than men?: Evidence from dictator experiments. The Economic Journal, 108(448), 726-735. https://doi.org/10.1111/1468-0297.00311

Freeland, R. E., Spenner, K. I., \& McCalmon, G. (2015). I gave at the campus: Exploring student giving \& its link to young alumni donations after graduation. Nonprofit \& Voluntary Sector Quarterly, 44(4), 755-774. https://doi.org/10.1177/0899764014529625

Glantz, S. A., \& Slinker, B. K. (1990). Primer of applied regression and analysis of variance. New York: McGraw-Hill.

Gaier, S. (2005). Alumni satisfaction with their undergraduate academic experience \& the impact on alumni giving \& participation. International Journal of Educational Advancement, 5(4), 279-288. https://doi.org/10.1057/palgrave.ijea.2140220

Glaser, B. G., \& Strauss, A. L. (1967). The discovery of grounded theory: Strategies for qualitative research. New York, NY: Aldine De Gruyter.

Guielford, J. P. (1965). Fundamental statistics in psychology \& education (4th ed.). New York, NY: McGraw-Hill.

Hon, L. C., \& Grunig, J. E. (1999). Guidelines for measuring relationships in public relations. Gainesville: Institute for Public Relations, University of Florida.

Hurvitz, L. A. (2013). Building a culture of student philanthropy. In N. Drezner (Ed.), Expanding the donor base in higher education: Engaging non-traditional donors (pp. 138-151). New York, NY: Routledge.

Jackson, E. F., Bachmeier, M. D., Wood, J. R., \& Craft, E. A. (1995). Volunteering \& charitable giving: Do religious \& associational ties promote helping behavior? Nonprofit \& Voluntary Sector Quarterly, 24(1), 59-78. https://doi.org/10.1177/089976409502400108

Kelly, K. S. (1998). Effective fund-raising management. Mahwah, NJ: Lawrence Erlbaum.

Kelly, K. S. (2002). The state of fund-raising theory \& research. In M. J. Worth (Ed.), New strategies for educational fund raising (pp. 39-55). Westport, CT: Praeger.

Lindahl, W. E., \& Winship, C. (1992). Predictive models for annual fundraising \& major gift fundraising. Nonprofit Management \& Leadership, 3(1), 43-64. https://doi.org/10.1002/nml.4130030105 
MacQuillin, I. (2016). Relationship fundraising: Where do we go from here? Volume 3-Trends \& challenges identified by practitioners. Plymouth, UK: Centre for Sustainable Philanthropy, Plymouth University.

MacQuillin, I., \& Sargeant, A. (2016). Relationship fundraising: Where do we go from here? Volume 4-summary report. Plymouth, UK: Centre for Sustainable Philanthropy, Plymouth University.

MacQuillin, I., Sargeant, A., \& Shang, J. (2016). Relationship fundraising: Where do we go from here? Volume 2-review of theory from social psychology. Plymouth, UK: Centre for Sustainable Philanthropy, Plymouth University.

Marr, K. A., Mullin, C. H., \& Siegfried, J. J. (2005). Undergraduate financial aid \& subsequent alumni giving behavior. Quarterly Review of Economics \& Finance, 45, 123-143. https://doi.org/10.1016/j.qref.2003.08.005

Martin, M. W. (1994). Virtuous giving: Philanthropy, voluntary service, \& caring. Bloomington: Indiana University Press.

Meer, J. (2011). Brother, can you spare a dime: Peer pressure in charitable solicitation. Journal of Public Economics, 95, 926-941. https://doi.org/10.1016/j.jpubeco.2010.11.026

Meer, J., \& Rosen, H. S. (2011). The ABCs of charitable giving. Journal of Public Economics, 95, 363-371. https://doi.org/10.1016/j.jpubeco.2010.07.009

Mitchell, M., Leachman, M., \& Masterson, K. (2016). Funding down, tuition up: State cuts to higher education threaten quality \& affordability at public colleges. Washington, DC: Center on Budget \& Policy Priorities. Retrieved from https://www.cbpp.org/research/state-budget-and-tax/funding-down-tuition-up

Monks, J. (2003). Patterns of giving to one's alma mater among young graduates from selective institutions. Economics of Education Review, 22, 121-130. https://doi.org/10.1016/S0272-7757(02)00036-5

Moorman, C., Deshpande, R., \& Zaltman, G. (1993). Factors affecting trust in market research relationships. Journal of Marketing, 57(1), 81-101. https://doi.org/10.1177/002224299305700106

Morgan, R. M., \& Hunt, S. D. (1994). The commitment-trust theory of relationship marketing. Journal of Marketing, 58(3), 20-38. https://doi.org/10.1177/002224299405800302

Nayman, R. L., Gianneschi, H. R., \& Mandel, J. M. (1993). Turning students into alumni donors. New Directions for Student Services, 63, 85-94. https://doi.org/10.1002/ss.37119936310

Piliavin, J. A., \& Charng, Hong-Wen. (1990). Altruism: A review of recent theory \& research. Annual Review of Sociology, 16, 27-65. https://doi.org/10.1146/annurev.so.16.080190.000331

Sargeant, A. (2001). Relationship fundraising: How to keep donors loyal. Nonprofit Management \& Leadership, 12(2), 177-192. https://doi.org/10.1002/nml.12204

Sargeant, A. (2016). Relationship fundraising: Where do we go from here? Volume 1-review of theory from relationship marketing. Plymouth, UK: Centre for Sustainable Philanthropy, Plymouth University.

Sargeant, A., \& Lee, S. (2004). Donor trust \& relationship commitment in the U.K. charity sector: The impact on behavior. Nonprofit \& Voluntary Sector Quarterly, 33(2), 185-202. https://doi.org/10.1177/0899764004263321

Sargeant, A., \& McKenzie, J. (1998). A lifetime of giving: An analysis of donor lifetime value. West Malling, UK: Charities Aid Foundation.

Sargeant, A., \& Shang, J. (2010). Fundraising principles \& practice. San Francisco, CA: Jossey-Bass.

Schervish, P. G., \& Havens, J. J. (1997). Social participation \& charitable giving: A multivariate analysis. Voluntas, 8 , 235-260. https://doi.org/10.1007/BF02354199

Sun, X., Hoffman, S. C., \& Grady, M. L. (2007). A multivariate causal model of alumni giving: Implications for alumni fundraisers. International Journal of Educational Advancement, 7(4), 307-332. https://doi.org/10.1057/palgrave.ijea.2150073

Weerts, D. J. (2007). Toward an engagement model of institutional advancement at public colleges \& universities. $\begin{array}{llll}\text { International Journal of Educational Advancement, } & 7(2), & \text { 79-103. }\end{array}$ https://doi.org/10.1057/palgrave.ijea.2150055

White, M. D., \& Marsh, E. E. (2006). Content analysis: A flexible methodology. Library Trends, 55(1), 22-45. https://doi.org/10.1353/lib.2006.0053 